DOI: 10.17951/lrp. 2018.37.1.55-74

\title{
Bożena Pietryczuk
}

Państwowa Wyższa Szkoła Zawodowa w Chełmie

\section{INTERAKCJE W PROCESIE SOCJALIZACJI RODZAJOWEJ DZIECI W PRZEDSZKOLU}

Streszczenie: W procesie socjalizacji dziecko uczy się podstaw interakcji społecznych, życia i funkcjonowania w grupie, poznaje społeczne normy postępowania i zachowania, kształtuje swoją osobowość i cechy charakteru. Jednym z najważniejszych zakresów tego rozwoju jest przygotowanie do pełnienia ról kobiety i mężczyzny. W procesie socjalizacji dzieci w zakresie kształtowania ról rodzajowych istotną rolę odgrywa przedszkole. Opisane badania dotyczą interakcji między nauczycielkami a wychowankami w przedszkolu oraz ich wpływu na kształtowanie płci społeczno-kulturowej (rodzaju) dzieci.

Słowa kluczowe: socjalizacja, interakcje, płeć, rodzaj

\section{WPROWADZENIE}

Przedszkole jako instytucja socjalizacyjna stosuje wobec dzieci - w formie bardziej lub mniej bezpośredniej - różnorodne praktyki socjalizacyjne. W ich zakres - obok przestrzeni fizycznej, aktywności dzieci (swobodnej i zorganizowanej) - wchodzą interakcje między nauczycielkami a dziećmi. Odgrywają one ważną rolę w kształtowaniu rodzaju (płci kulturowo-społecznej) dziewczynek i chłopców.

Termin interakcje oznacza wzajemne oddziaływanie na siebie osób, przedmiotów, a także wymagania, jakie partnerzy interakcji stawiają wobec siebie i własnego działania (Okoń 2007, s. 143). Krzysztof Konarzewski (1995, s. 124) pojęciem tym określa treść i sposób inicjowania dydaktycznych i pozadydaktycznych kontaktów nauczycielki z dzieckiem oraz reagowanie na zachowanie dziecka oraz interakcyjne epizody. Interakcje nie stanowią jednak - jak podkreśla Herbert Blumer - prostego procesu wyzwalania oczekiwanych zachowań, są środkiem nieustannego dostosowywania się, interpretacji wzajemnych poczynań (Blumer 1984, s. 76). 
Interakcje, które zachodzą w przedszkolu, oznaczają, że osoby przebywające w grupie (dzieci i nauczycielki) kontaktują się ze sobą, rozmawiają, porozumiewają się pozawerbalnie, współpracują, a niekiedy nawet walczą fizycznie lub symbolicznie (Janowski 1998, s. 100).

Interakcje są podstawowym nośnikiem oczekiwań, postaw i wymagań nauczycielek wobec dzieci i odwrotnie. Istnieje jednak między nimi zasadnicza różnica, polegająca na tym, że odbiór nadawanych sygnałów przez nauczycielki jest zwykle podporządkowany idei oceniania (co wynika z tzw. nauczycielskiego widzenia świata), zgodnie $\mathrm{z}$ którą zachowania i oceny dziecka są rozpatrywane głównie w perspektywie: „grzeczny-niegrzeczny” i „dobry uczeń-zły uczeń” (Janowski 1998, s. 104).

Przedszkole, jako miejsce specyficznego życia społecznego, narzuca interakcjom pewne ramy, które determinują i ujednolicają warunki ich tworzenia i wyznaczają im kontekst. Na kształt i przebieg tych procesów zasadniczy wpływ mają osoby nawiązujące interakcje (zwykle nauczycielki) oraz rodzaj interakcji (werbalne lub niewerbalne). Interakcje zachodzące w przedszkolu są „zorganizowane społecznie i osadzone w kulturowych systemach znaczeniowych" (Schieffelin, Ochs 1995, s. 126). Procesom tym George Mead nadał miano procesu komunikacji, a Jurgen Habermas - komunikacji językowej lub działania komunikacyjnego (Mead 1975; Habermas 1999; por. Tillmann 2010, s. 143-145).

Komunikacja werbalna (język, mowa) ${ }^{1}$ wypełnia edukacyjną rzeczywistość najważniejsze w niej jest bowiem mówienie (Barnes 1988, s. 11), które „poprzez zmysłową bezpośredniość ma człowieka we władaniu, osacza aurą perswazji, siłą ekspresji osobowej. Mowa bardziej niż pismo kolonizuje myśli i uczucia człowieka" (Kwiatkowska 2000, s. 27), pozwala na komunikowanie się ze sobą, myślenie, interakcje społeczne i społeczną kontrolę. Z jednej strony język jest środkiem do przekazywania idei, spostrzeżeń i pojęć, a z drugiej środkiem, dzięki któremu jednostki porządkują osobiste przeżycia społeczne, przemyślenia i stosunki z innymi ludźmi (Schaffer 2013, s. 295; Walker, Meighan 1993, s. 159-160).

\section{BADANIA WŁASNE}

Zrealizowany projekt badawczy mieści się w paradygmacie interpretatywnym, w perspektywie jakościowej. Tematyka badań wymagała uczestniczenia w życiu przedszkola, w związku z czym wykorzystana została metoda etnograficzna. Podstawową technikę badawczą stanowiła obserwacja, która nierozerwalnie łączy

\footnotetext{
${ }^{1}$ Pojęcia te dla uproszczenia stosowane są zamiennie.
} 
się z etnografią. Obserwacji poddałam codzienne życie 4 miejskich przedszkoli, a w nich 4 grupy dzieci pięcio- i sześcioletnich oraz osoby pracujące $\mathrm{z}$ nimi. Szczególny nacisk położyłam na obserwację 8 nauczycielek - wychowawczyń pracujących z tą grupą wiekową. Dokonałam 121 obserwacji różnych sytuacji, m.in.: swobodnej działalności dzieci, zajęć obowiązkowych, spacerów, uroczystości, spożywania posiłków i odpoczynku. Kolejną techniką był wywiad. Ogółem przeprowadziłam 18 wywiadów (z pracownikami pedagogicznymi i niepedagogicznymi), skoncentrowałam się jednak na informacjach uzyskanych w rozmowach z 8 wspomnianymi wychowawczyniami. Badania trwały 10 miesięcy, poświęciłam na nie około 72 godzin ${ }^{2}$.

Obserwacja jako akt spostrzegania faktów, zjawisk i systematycznego rejestrowania ich, często za pomocą odpowiednich narzędzi oraz wszystkich zmysłów, pozwala „głębiej” doświadczać badanej rzeczywistości (Angrosino 2010, s. 106; Janowski 1985, s. 164; Łobocki 2011, s. 48). W zastosowanej obserwacji etnograficznej pierwszorzędną rolę odgrywa obserwator, który - oprócz gromadzenia danych - ma bardzo trudne zadanie, polegające na odpowiednim zaklasyfikowaniu ich i zinterpretowaniu (Łobocki 2011, s. 49). Osoba ta powinna charakteryzować się wysokim poziomem empatii, dobrą pamięcią, umiejętnościami interpersonalnymi, analitycznymi, pisarskimi oraz umiejętnością syntetyzowania (Rubacha 2001, s. 22; Angrosino 2010, s. 111).

W przywołanych badaniach dominującą strategią była obserwacja uczestnicząca. Uczestnicy badania wiedzieli, kim jestem i wyrazili na zgodę na moją obecność (por. Gold, za: Kubinowski 2010, s. 201). Byłam więc osobą znaną i rozpoznawalną przez badane osoby i chociaż wchodziłam z nimi w interakcje, to jednak pozostawałam badaczką, która skrzętnie i dyskretnie notowała obserwacje.

Przedmiotem obserwacji było m.in. zachowanie nauczycielek w relacjach z dziećmi, zwłaszcza ich przekazy językowe i sposób komunikowania się. Szczególną uwagę zwróciłam na zróżnicowanie zachowania nauczycielek w stosunku do dziewczynek i chłopców oraz stosowane wobec dzieci obu płci praktyki socjalizacyjne.

\section{WYNIKI BADAŃ}

W podstawowy zakres interakcji/komunikowania się nauczycielek z dziećmi wchodziło przekazywanie „właściwej” wiedzy i sterowanie zachowaniem dziew-

${ }^{2}$ Opisane badania stanowią fragment rozbudowanego projektu badawczego, na podstawie którego powstała rozprawa doktorska pt. Socjalizacja rodzajowa dzieci w przedszkolu, napisana na Wydziale Pedagogiki i Psychologii UMCS w Lublinie pod kierunkiem prof. UMCS Doroty Pankowskiej. 
czynek i chłopców. Do tego celu nauczycielki wykorzystywały akty ewaluacyjne i pragmatyczne (zob. typologia A. Awdiejewa i Z. Nęckiego - Nęcki 1996, s. 131). Omówię tylko niektóre - najczęściej stosowane w praktykach socjalizacyjnych: pochwałę, krytykę, lekceważenie i ocenę (akty ewaluacyjne) oraz obietnicę, prośbę, radę i żądanie (akty pragmatyczne).

Pochwała służyła do motywowania dzieci do działania i regulowania zachowania. Kierowana była często do dzieci mniej aktywnych, nieśmiałych i słabiej radzących sobie w pewnych zakresach działalności edukacyjnej. Oto parę przykładów: „Zobaczcie, jakie piękne szlaczki zrobił Kubuś!” - pani A1³ głośno mówi do całej grupy. Chłopiec uśmiecha się pod nosem, widać, że jest zadowolony. Kuba unikał rysowania szlaczków, nie kończył ich. Tym razem, po usłyszeniu takich słów, siedział przy nich dotąd, aż je skończył. Pochwała zmotywowała chłopca do pracy. Kolejny epizod: „No, aż miło posłuchać. Julka, widzę, że wzięłaś się do roboty". Komunikat skierowany był do dziewczynki, która bezbłędnie podzieliła kilka kolejnych wyrazów na sylaby i głoski. Julia długo miała z tym problem, głośno wypowiedziana pochwała była zachętą do większego wysiłku.

Strategia ta przynosiła pozytywne skutki w różnych sytuacjach, np. podczas:

- sprzątania po zajęciach lub zabawie: „Chłopcy brawo! To miła niespodzianka" - pani A2 skierowała te słowa do Bartka, Wojtka i Igora, którzy wrzucili klocki do skrzyni, a zrobili to za siebie i swoich kolegów, z którymi się bawili. Komunikat ten zawiera w sobie ukryty przekaz - sprzątanie nie jest domeną chłopców, stąd zaskoczenie nauczycielki i słowa „miła niespodzianka";

- przebierania się do ćwiczeń gimnastycznych: „W mojej grupie sami sportowcy!” - reakcja na szybką i sprawną zmianę ubrania przez niektóre dziewczynki i chłopców;

- posiłku: „Muszę przyznać Maja, że dzisiaj pięknie zjadłaś surówkę, prawda dzieci?" - słowa skierowane do dziewczynki unikającej surowych warzyw.

Na podobnych zasadach działały komunikaty wyrażające podziw i uznanie. Dotyczyły one zwykle „dużych” sukcesów dzieci, odniesionych m.in. w konkursach, spartakiadach, po udanych występach na uroczystościach przedszkolnych, ale też bardzo dobrego wykonania jakiejś pracy oraz zachowania. „Jowita to był twój najlepszy występ" (pani A1 z uznaniem w głosie przekazała dziewczynce wiadomość po zakończeniu międzyprzedszkolnego konkursu recytatorskiego); „Kajetan twój rysunek okazał się najciekawszy” (informacja skierowana do chłopca po rozstrzygnięciu konkursu plastycznego - D2); „Och, jaki cudowny zamek” (pani

${ }^{3}$ Badane przedszkola otrzymały nazwę A, B, C i D. Symbol A1 oznacza starszą nauczycielkę w przedszkolu A, natomiast A2 - młodszą. Pozostałe odpowiednio B1, B2, C1, C2, D1, D2. 
B1 podziwiała wzniesioną przez chłopca budowlę, którą się pochwalił); „Muszę przyznać, że zachowałeś się wspaniale" (pani C1 zwróciła się do Piotrka, który oddał swoją zabawkę płaczącemu bratu). Nauczycielki kierowały szczególne słowa uznania do tych dzieci, które były wyróżnione przez dyrektorkę, przedstawiciela/-kę organu prowadzącego, jury jakiegoś konkursu itp., czyli do wychowanków przynoszących im dumę.

Pochwała, podziw i uznanie działały na dziecko jak czarodziejska różdżka, bo na tę chwilę jego postępowanie przybierało postać wzorcowego (to znaczy takiego, jakiego życzyła sobie nauczycielka). Miały jednak znamiona manipulacji, której dzieci bezwiednie się poddawały - zarówno dziewczęta, jak i chłopcy.

Kolejne strategie stosowane przez nauczycielki to krytyka i lekceważenie, które w odróżnieniu do wymienionych aktów ewaluacyjnych miały negatywne zabarwienie. Odnosiły się do nieodpowiedniego zachowania dziecka. Pojawiały się zwykle w sytuacjach pośpiechu, rozdrażnienia nauczycielki, braku reakcji lub niewłaściwie wykonanego zadania: „No nie, ty jak zwykle się guzdrasz! Nie włożyłeś nawet butów!” - podniesionym głosem nauczycielka zwróciła się do Dawida. W tym dniu zaplanowała wyjście do pobliskiego parku, chłopiec przez swoją opieszałość „kradł” czas przeznaczony na ten cel. Chłopiec, jak wynikało z mojej obserwacji, był może nie tyle powolny, co mało samodzielny. W rozmowie prowadzonej z nauczycielką podczas spaceru dowiedziałam się, że Dawidem zajmowała się często nadopiekuńcza babcia. Prawdopodobnie wyręczała wnuka w wykonywaniu czynności samoobsługowych ${ }^{4}$.

Prośba nauczycielki skierowana do dzieci była jednoznaczna z nakazem. Z kolei prośby dzieci wnoszone do niej były czasami lekceważone. Dotyczyły one zwykle wydłużenia czasu zabawy, pobytu na świeżym powietrzu i kierowane były częściej przez chłopców niż dziewczęta.

Przykład 1:

Przed śniadaniem nauczycielka poleciła dzieciom usiąść na dywanie. Wszystkie dziewczynki to uczyniły, chłopcy też poza kilkoma, którzy nadal bawili się klockami. Podeszła do nich pani A1, mówiąc:

N.: „Sprzątamy klocki!”

Chłopcy (chórem) proszącym głosem: „O nieeee”.

Chłopiec 1: „Jeszcze trochę".

Chłopiec 2: „Prosimy”.

${ }^{4}$ We wszystkich badanych przedszkolach była grupa (1-3) chłopców mało samodzielnych. Niezaradność dotyczyła różnych czynności: ubierania/rozbierania, organizowania sobie warsztatu pracy (np. przygotowanie kredek, ołówków do wypełniania kart pracy), spożywania posiłków (brak łyżki, widelca, kompotu itp.) Wówczas głośno komunikowali, że czegoś nie mają, czekając aż ktoś im to poda. Wśród dziewcząt nie zaobserwowałam podobnej sytuacji. 
Nauczycielka nie zareagowała na słowa chłopców, odwróciła się do nich plecami, podeszła do biurka, wzięła dziennik i zaczęła sprawdzać listę obecności. Chłopcy po chwili zaczęli zbierać klocki, ponieważ doskonale wiedzieli, że zachowanie nauczycielki nie było przyzwoleniem na dalszą zabawę, lecz niewerbalnym komunikatem bezdyskusyjnego jej zakończenia (podczas sprawdzania listy obecności dzieci miały siedzieć na dywanie i uważnie słuchać).

Przykład 2:

Dzieci lubiły dzielić się z nauczycielką wiadomościami z życia prywatnego, najczęściej jakimś „ciekawym” wydarzeniem. W poniedziałek rano do biurka, przy którym siedziała nauczycielka i wypełniała jakieś dokumenty, podeszła Oliwia i zaczęła rozmowę:

Oliwia: „Wczoraj przyjechała do mnie ciocia ze Szczecina”.

N.: ?? - pani C1 pisze dalej, nie podnosząc na dziewczynkę nawet wzroku.

Oliwia: „Przywiozła mi prezenty”.

N.: „Yhy” - odpowiedziała, rzucając na dziewczynkę obojętne spojrzenie.

Oliwia: „Sukienkę i zabawki z Portugalii” - kontynuuje dziewczynka niezrażona brakiem zainteresowania wychowawczyni.

N.: „Taaak? Później mi opowiesz, teraz jestem zajęta. Idź się pobawić” (OC1/14).

Dla Oliwii wizyta cioci była wielkim wydarzeniem, ponieważ rzadko przyjeżdżała do dziewczynki i jej rodziców ze względu na charakter pracy - pływała jako oficer na statkach. Nauczycielka, pochłonięta biurokratycznymi czynnościami, nie słuchała dziewczynki. A szkoda, bo przypadek cioci pracującej w zawodzie przypisywanym dotąd mężczyznom mógłby stanowić doskonały pretekst do rozmowy na temat niestereotypowych ról zawodowych kobiet i mężczyzn.

Dzieci w przedszkolu poddawane były również ustawicznemu ocenianiu głównie za zachowanie, wiedzę i pracę. Za jego pośrednictwem otrzymywały komunikaty na temat tego, co powinny wiedzieć, co robić, jakie zachowanie przystoi lub nie dziewczynce i chłopcu. Nauczycielki, oceniając dzieci, stosowały zwykle kategorię grzecznego i niegrzecznego dziecka, która w przedszkolu stanowiła ogólnie obowiązującą zasadę. Oto kilka przykładów:

a) Nauczycielka, która miała zastępstwo za nieobecną koleżankę (panią C1), już pierwszego dnia pracy z tą grupą oznajmiła wychowankom, że lubi tylko grzeczne dzieci, a niegrzecznych nie lubi;

b) Podczas zajęć dzieci zaczęły się przekrzykiwać, zapominając o tym, że należy podnieść palec do góry i czekać, aż pani udzieli głosu. Nauczycielka Al uciszyła je i poinformowała, że do odpowiedzi weźmie to dziecko, które jest najgrzeczniejsze;

c) Przed wyjściem na plac zabaw jeden z chłopców wygłupiał się, reakcja pani C1 była następująca: „Jasiek jest niegrzeczny, więc będzie szedł jako ostatni”. 
Jak widać z powyższego opisu, bez względu na poglądy nauczycielki dotyczące odpowiednich zachowań dziewczynek/chłopców, kategoria grzeczności była nadrzędna wobec obu płci.

Kategoria grzecznego dziecka okazała się również skutecznym narzędziem do oceny jego wyglądu. Pomoc nauczycielki, która pilnowała dzieci podczas chwilowej nieobecności nauczycielki w sali, powiedziała do rozrabiającej dziewczynki: „Taka ładna dziewczynka powinna być grzeczna”. Podobne komunikaty trafiały również do chłopców. Podczas swobodnej zabawy dzieci pani A2 odezwała się do chłopca w następujący sposób: „Grzesiu szalejesz i wycierasz kolanami wszystkie kąty, a jesteś dzisiaj taki elegancki" (chłopiec w tym dniu miał urodziny, więc do przedszkola przyszedł ubrany odświętnie; bawił się samochodem, ,jeździł” nim po podłodze). Warto jednak zwrócić uwagę na subtelną różnicę $\mathrm{w}$ treści obu, pozornie podobnych w swej wymowie, komunikatów: uroda jest cechą raczej wrodzoną, a elegancja - pewnym sposobem ubierania się, zależnym od podmiotu. W przypadku komunikatu kierowanego do dziewczynki można zauważyć jeszcze drugą warstwę, często występującą w baśniach: łączenie $\mathrm{z}$ urodą innych pozytywnych cech i odwrotnie $-\mathrm{z}$ brzydotą negatywnych atrybutów. Można też zastanowić się nad wpływem tego połączenia: ładna = grzeczna/dobra na stosunek dzieci do dziewczynek niezbyt urodziwych oraz na poczucie własnej wartości osób, które nie postrzegają siebie jako ładne.

Wymaganie od dzieci grzecznego zachowania, niebrudzenia się (dbania o wygląd) jest zgodne z kobiecym wzorcem socjalizacyjnym, który dominuje w środowisku przedszkolnym, co wynika m.in. z feminizacji zawodu.

Kolejną grupę aktów komunikacyjnych tworzyły operacje pragmatyczne, do których należały: rada, prośba, żądanie i obietnica. Służyły one głównie ograniczaniu swobody dzieci i potwierdzały jednocześnie asymetryczny charakter komunikacji przedszkolnej. Usłyszana przez dziecko rada lub prośba nauczycielki zobowiązywała je do zastosowania się do niej, czego potwierdzeniem jest następująca sytuacja: „Kuba posprząta zabawki i usiądzie przy stole” - powiedziała nauczycielka do chłopca. Chłopiec podczas zajęć nie dokończył uzupełniania karty pracy i teraz (jest już po podwieczorku) ma to zrobić. Wychowawczyni dodaje, zwracając się do jednej z dziewczynek: „Weroniczko, pomożesz Kubusiowi?”, Weronika bez słowa sprzeciwu przerywa zabawę i siada przy chłopcu, by pomóc mu wykonać zadania w kartach pracy ${ }^{5}$. Fakt zwrócenia się do dziewczynki z poleceniem udzielenia pomocy koledze i jej „naturalna” reakcja wyrażająca pełną akceptację dla prośby nauczycielki (choć musiała $\mathrm{z}$ tego powodu przerwać zabawę) to również

${ }^{5}$ Weronika to bardzo zdolna i aktywna dziewczynka, Kuba natomiast niechętnie podchodził do obowiązków związanych z nauką. 
informacja dla pozostałych dzieci: dziewczynki/kobiety powinny być nastawione na pomaganie innym, nawet kosztem własnych potrzeb.

Najczęstszym doświadczeniem socjalizacyjnym dziecka w przedszkolu nierozerwalnie łączącym się z radą i prośbą - było instruowanie. Dotyczyło ono w zasadzie każdego typu działalności - od czynności samoobsługowych, przez zabawę do zajęć dydaktycznych. Przykładem instruktażu dotyczącego czynności samoobsługowych był komunikat nauczycielki wypowiedziany do chłopca podczas ubierania się dzieci w szatni: „Mówiłam tyle razy, najpierw wkładamy buty, a potem kurtkę". Jędrzej włożył kurtkę, czapkę i szalik, po czym zaczął wkładać buty. Instrukcje $\mathrm{w}$ zakresie czynności organizacyjno-porządkowych przybierały m.in. taką formę: „Dziewczynki ustawiają się przed łazienką. Dyżurna dopilnuje, by wszystkie umyły dokładnie mydłem ręce. Chłopcy siadają na dywanie. Możecie sobie cichutko porozmawiać" (sytuacja pokazująca przygotowanie dzieci do śniadania). Podobne komunikaty miały miejsce podczas zajęć: dzieci siedział przy stolikach, na których nauczycielka postawiła tace z masą solną w trzech kolorach: czerwonym, żółtym i zielonym. Instrukcja udzielona dzieciom brzmiała następująco: „Z masy solnej zrobicie dowolne warzywo, na przykład z czerwonej może być pomidor lub burak, z żółtej marchewka itd.”. Nauczycielka podchodziła potem do dzieci i sprawdzała, co już zrobiły. Stanęła przy jednym ze stolików i zwróciła się do Michała: „Zrobiłeś tylko tyle? Jest jeszcze zielona masa, zrób paprykę albo... no nie wiem, może pora”. Instrukcje miały ułatwić dzieciom wykonanie zadania, a nauczycielce osiągnięcie jak najlepszego efektu (ładnych ulepianek) ${ }^{6}$. Instruowanie ograniczało samodzielność dzieci, możliwości planowania, organizowania własnych działań oraz trening własnych umiejętności.

Kolejna, często pojawiająca się strategia to żądanie, które sprowadzało się zazwyczaj do dyscyplinowania i kontrolowania dzieci. Prawo do kontroli - z racji wyższej pozycji - przysługiwało nauczycielce, dzieciom natomiast wyznaczana była rola kontrolowanych. Sposób wprowadzania dyscypliny zależał od stopnia dyrektywności nauczycielek - jednym przychodziło to z łatwością i większą skutecznością, inne miały z tym problem, np. nauczycielki A2 i D2. Dyscyplinowanie i kontrolowanie dzieci przyjmowało formę nakazów i zakazów. Oto dwa przykłady zastosowania nakazów:

1) Dzieci siedziały w półkolu na dywanie przed tablicą. Nauczycielka czytała wiersz o wiośnie, w którym poetka zastosowała wiele wyrazów dźwiękonaśladowczych, co wymagało ciszy i uwagi ze strony dzieci. Jeden z chłopców nie słuchał, kręcił się, zaczepiał kolegów. Nauczycielka przerwała czytanie,

${ }^{6}$ Prace dzieci pokazywane były na wystawach na korytarzu lub holu, które organizowano głównie dla rodziców. Stanowiły one efekt pracy nie tylko dzieci, ale również nauczycielki, pod kierunkiem której je wykonały. 
w milczeniu rzuciła mu groźne spojrzenie. Na chwilę chłopiec uspokoił się. Nauczycielka wróciła do czytania, a wychowanek do poprzedniego zachowania. Po chwili pani ponownie przerwała czytanie, tym razem powiedziała: „Kacper podejdź i usiądź przy mnie!” Chłopiec powoli wstał i usiadł, jak nakazała nauczycielka (OB2/11).

2) „Dziewczynki już skończyły? Usiądźcie na dywanie, weźcie sobie jakąś układankę". Dzieci uzupełniały karty pracy, kilka dziewczynek zrobiło to szybciej niż ich koleżanki i koledzy. Otrzymany komunikat wyznaczył dziewczynkom miejsce i rodzaj zabawy (OD1/10).

Zakazy dotyczyły głównie zachowania i zabawy, stanowiły rodzaj kary, np. zakaz zabawy chłopców samochodami (w sytuacji nieposłuszeństwa lub nieodpowiedniego ich użytkowania) lub zabawy dziewczynek lalkami (z tych samych powodów). Przykład 1:

Kamila i Zuzia wzięły wózki z lalkami i urządziły w sali wyścigi. Biegały wzdłuż sali, kilkakrotnie przewracając się z wózkiem. Lalki, które podczas tych manewrów upadały na podłogę, dziewczynki wrzucały z powrotem do wózka i biegły dalej. Pani C1, zobaczywszy zabawę dziewczynek, aż poczerwieniała na twarzy i krzyknęła: „Wózki z lalkami na miejsce! Jeśli nie umiecie ładnie się bawić, nie macie wstępu do kącika lalek!”.

Zakaz wchodzenia do kącika lalek i zabawy wózkami wynikał głównie z tego, że dziewczynki używały zabawek niezgodnie z ich przeznaczeniem. Nauczycielka swoją reakcją przekazała jeszcze inny komunikat: dziewczynki powinny ładnie się bawić, to znaczy opiekować się lalkami, troszczyć się o nie i spokojnie wozić je w wózku. Nadmierna aktywność ruchowa - bieganie, organizowanie wyścigów wózków (współzawodnictwo) im nie przystoi. Dziewczynki wyłamujące się z ram stereotypów zasługują na karę.

Przykład 2:

Na placu zabaw chłopcy zorganizowali zabawę w wojnę: łopatki do piasku zastępowały karabiny maszynowe lub pistolety. W tym czasie nauczycielka zajęta była rozmową z dziewczynkami, które popisywały się gimnastycznymi umiejętnościami - robieniem mostka, szpagatu itp. Do nauczycielki podszedł Mikołaj i poinformował panią o zabawie kolegów (Mikołaj był chłopcem mało sprawnym ruchowo i koledzy niechętnie włączali go do zabawy wymagającej zręczności, poza tym zabawa w wojnę była zabroniona). Reakcja pani B2 była natychmiastowa: przywołała imiennie chłopców i wyraziła niezadowolenie $\mathrm{z}$ łamania ustalonych reguł. Przez 10 minut mieli zakaz jakiejkolwiek zabawy, siedzieli na ławce obok pani.

Ten przykład pokazuje, podobnie jak wcześniej opisane zachowanie nauczycielki C1, która jako priorytet traktowała normę „grzeczności”, że oprócz standardów rodzajowych ważne przede wszystkim jest przestrzeganie narzuconych dzieciom reguł. 
Nakazami, zakazami, stałą kontrolą nauczycielki sterowały działalnością dzieci, skutkiem czego było m.in. permanentne zadawanie pytań. Wychowankowie pytali niemal o wszystko - o pozwolenie rysowania, wzięcia zabawki, wyjścia do toalety, zdjęcie sweterka, zjedzenie cukierka itp. Czynili to, aby wiedzieć, jakie są oczekiwania nauczycielki, do których należało się dostosować.

Dziewczynki, jak mówiły nauczycielki, bardziej niż chłopcy starały się dopasować do wymagań i w związku z tym zadawały więcej pytań o pozwolenie, co sprawiało, że chłopcy wydawali się bardziej niezależni, ale też i mniej posłuszni ${ }^{7}$. Dostosowanie/niedostosowanie się dzieci do nakazów i zakazów sterowane było za pomocą nagród i kar, którymi - jak podkreślały nauczycielki - na równi „obdarzały” dziewczynki i chłopców. Jakie zachowania dziewczynek i chłopców były nagradzane, a jakie karane, w jaki sposób i co stanowiło tę nagrodę/karę, pokazują tabele 1, 2 i 3 .

Z przeprowadzonych z nauczycielkami wywiadów wynika, że nagradzały dzieci przede wszystkim za: dobre zachowanie, aktywność podczas zajęć, utrzymanie porządku oraz pełnione dyżury (tabela 1).

Tabela 1. Nagradzanie dziewcząt i chłopców

\begin{tabular}{|c|c|c|c|}
\hline $\begin{array}{c}\text { Wypowiedzi nauczycielek } \\
\text { odnośnie do zachowania } \\
\text { dziewcząt }\end{array}$ & Lącznie & $\begin{array}{l}\text { Wypowiedzi nauczy- } \\
\text { cielek odnośnie do } \\
\text { zachowania chłopców }\end{array}$ & Łącznie \\
\hline $\begin{array}{l}\text { „Za aktywność na zajęciach, } \\
\text { za dobrze wykonane dyżury, } \\
\text { za to, że posprzątają zabawki, } \\
\text { nie tylko swoje, ale i kolegów } \\
\text { - generalnie za zachowanie, } \\
\text { które może być wzorem dla } \\
\text { innych” (A1); } \\
\text { „Za sprzątanie po sobie, za } \\
\text { dobrą pracę na zajęciach, za } \\
\text { zachowanie” (A2); } \\
\text { „Za aktywność na zajęciach, za } \\
\text { zachowanie” (B1); } \\
\text { „Za aktywność, zachowanie, } \\
\text { pomoc innym lub za to, że za- } \\
\text { miecie, coś przyniesie, wytrze } \\
\text { stół itp.” (B2); } \\
\text { „Za dobrze wykonane zadanie, } \\
\text { aktywność na zajęciach, } \\
\text { kulturalne zachowanie, ładną } \\
\text { zabawę, koleżeństwo, zgodną }\end{array}$ & $\begin{array}{l}\text { Zachowanie - } 6 \\
\text { Aktywność - } 6 \\
\text { Sprzątanie i utrzyma- } \\
\text { nie porządku - } 4 \\
\text { Dobry dyżur - } 3 \\
\text { Współdziałanie - } 2 \\
\text { Posłuszeństwo - } 1 \\
\text { Pomoc innym -1 } \\
\text { Grzeczna zabawa - } 1\end{array}$ & $\begin{array}{l}\text { „Za dobre } \\
\text { zachowanie"(A1); } \\
\text { „Za dobre zachowa- } \\
\text { nie” (A2); } \\
\text { „Za zachowanie, } \\
\text { sprzątanie po sobie } \\
\text { zabawek” (B1); } \\
\text { „Za zachowanie, } \\
\text { utrzymanie porządku } \\
\text { wokół siebie, poukła- } \\
\text { danie zabawek” (B2); } \\
\text { „Za to samo, co } \\
\text { dziewczynki” [tzn. } \\
\text { sprzątanie - uzup. } \\
\text { B.P.] (C1, 2); } \\
\text { „Za zachowanie, za } \\
\text { pracę i aktywność na } \\
\text { zajęciach” (D1); } \\
\text { „Za to samo, co } \\
\text { dziewczynki” [tzn. za }\end{array}$ & $\begin{array}{l}\text { Zachowanie - } 7 \\
\text { Sprzątanie i utrzyma- } \\
\text { nie porządku - } 3 \\
\text { Aktywność - } 2 \\
\text { Dobry dyżur -1 } \\
\text { Grzeczna zabawa - } 1\end{array}$ \\
\hline
\end{tabular}

${ }^{7}$ Informacje uzyskane w przeprowadzonych z nauczycielkami wywiadach. 


\begin{tabular}{|l|l|l|l|}
\hline \multicolumn{1}{|c|}{$\begin{array}{c}\text { Wypowiedzi nauczycielek } \\
\text { odnośnie do zachowania } \\
\text { dziewcząt }\end{array}$} & Lącznie & $\begin{array}{c}\text { Wypowiedzi nauczy- } \\
\text { cielek odnośnie do } \\
\text { zachowania chłopców }\end{array}$ & Eącznie \\
\hline $\begin{array}{l}\text { zabawę w grupie, współdziała- } \\
\text { nie” (C1); }\end{array}$ & $\begin{array}{l}\text { dyżur, grzeczne za- } \\
\text { chowanie, dokończe- } \\
\text { nie pracy, za zjedzenie } \\
\text { obiadu, grzeczną }\end{array}$ & \\
$\begin{array}{l}\text { dokładnie, a chłopcy byle } \\
\text { jak" (C2); }\end{array}$ & $\begin{array}{l}\text { zabawę - uzup. B.P.] } \\
\text { (D2) }\end{array}$ & \\
"Za dobry dyżur, posłuszeń- & & & \\
stwo" (D1); & & & \\
„Za dyżur, grzeczne zacho- & & & \\
wanie, dokończenie pracy, za & & & \\
zjedzenie obiadu, grzeczną & & & \\
zabawę itp." (D2) & & & \\
\hline
\end{tabular}

Źródło: opracowanie własne na podstawie przeprowadzonego wywiadu. W kolumnie drugiej i czwartej podana liczba oznacza, ile nauczycielek wskazało dany rodzaj zachowań

Pomimo deklaracji, że nagradzają „za to samo i dziewczynki, i chłopców”, to lista nagradzanych zachowań dziewczynek, podobnie jak częstotliwość ich występowania i różnorodność, nie była taka sama. W zakresie utrzymywania porząaku i czystości nauczycielki większe wymagania stawiały dziewczętom niż chłopcom: „Nagradzam dziewczynki za to, że posprzątają zabawki, nie tylko swoje, ale i kolegów” (A1), że „zamiotą, wytrą stół, coś przyniosą” (B2); „Dziewczynki chętniej i dokładniej sprzątają, a chłopcy nie, zwykle byle jak" (C2). Są to niewątpliwie prace porządkowo-usługowe, które wymagają dbałości, pamięci o szczegółach, pracowitości i systematyczności. Do wykonywania tych czynności niepotrzebne są szczególne ambicje, pomysłowość czy odwaga. Obowiązki związane z dyżurowaniem lepiej wypełniały dziewczynki - jak zaznaczyła jedna z nauczycielek (C2): „do tego potrzebna jest kobieca ręka”. Dziewczynki prawdopodobnie częściej niż chłopcy podobne czynności wykonywały w domu: dbanie o porządek, estetykę otoczenia, zwracanie uwagi na drobiazgi, a także - co również zaobserwowałam - w przedszkolu. Pochwały nauczycielki wzmacniały ich zaangażowanie w czynności porządkowe.

Nauczycielki nagradzały też dziewczęta za niesienie pomocy innym, współdziałanie, altruizm: „nagradzam dziewczynki za pomoc innym” (B2), „zgodną zabawę w grupie i współdziałanie” (C1), nie oczekując tego od chłopców. Od dziewcząt wymagały także większego posłuszeństwa mimo tego, że - jak mogłam zaobserwować oraz jak twierdziły same nauczycielki - były one bardziej posłuszne niż chłopcy. Przykładanie większej wagi do tych zachowań i nagradzanie ich świadczyć może o kierowaniu się stereotypami rodzajowymi, które uczą dziewczynki posłuszeństwa, dbania o porządek, wrażliwości, troskliwości, angażowania się 
w sprawy innych, to znaczy wykształcenia cech kobiecości (por. Inwentarz Płci Psychologicznej A. Kuczyńskiej).

W jaki sposób nauczycielki nagradzały dziewczynki, a w jaki chłopców? Dzieci najczęściej nagradzane były przez: słowną, głośno wypowiedzianą pochwałę lub pieczątkę w karcie pracy, naklejkę z „buźką” lub „słoneczkiem”, medal zrobiony z papieru lub folii, obrazek do pokolorowania, a także pełnienie dyżuru. Czasami jakiś gadżet lub reklamę ze sklepu sieciowego. Nagrodą, którą wszyscy otrzymywali, było wyjście na dwór, na plac zabaw, na spacer. Bardzo ważną, prestiżową wręcz nagrodą było stanie w pierwszej parze, policzenie dzieci na placu zabaw, poprowadzenie grupy do szatni, ocenianie prac plastycznych innych dzieci i uzasadnienie tej oceny (informacja uzyskana od nauczycielek oraz własna obserwacja). O taką nagrodę były największe starania - wydaje się, że chłopcy bardziej zabiegali o nią niż o inne. Być może dlatego, że tego rodzaju nagrody wiążą się z uzyskaniem uprzywilejowanej pozycji w grupie, uznaniem i pewną władzą, co w dorosłym życiu jest znamienne dla płci męskiej. Dzieci lubiły również, gdy nauczycielka pochwaliła je przed rodzicami, np. za dobre zachowanie, aktywność na zajęciach, zjedzony obiad, koleżeństwo, ładną zabawę itp. Starały się o taką pochwałę i nawet upominały się o nią. Prawdopodobnie rodzice w jakiś sposób także gratyfikowali dobre zachowanie dziecka w przedszkolu.

Moją uwagę zwróciła treść tych nagród. Na przykład kolorowanki, które dzieci otrzymywały w nagrodę, nie były jednakowe: dziewczęta dostawały kolorowankę przedstawiającą księżniczkę, postać Barbie w różnych pozach i sytuacjach, Hello Kitty, tancerki itp., chłopcy natomiast kolorowanki o tematyce sportowej, militarnej lub z męskimi postaciami znanych bajek - tzw. superbohaterów (fotografia 1 i 2). Gadżety przynoszone z dużych sklepów sieciowych również odnosiły się do konkretnej płci i nauczycielki zwykle wręczały je, kierując się sugestią producenta. Były to m.in.: gazetki reklamujące zabawki dla dziewczynek i dla chłopców, breloczki, naklejki, żetony, znaczki z wizerunkiem postaci rodzaju żeńskiego lub męskiego.

Dzieci, jak już wspomniałam, rzadziej były karane niż nagradzane i wachlarz kar był też mniejszy. Zasadniczo - według deklaracji nauczycielek - wszystkie dzieci karane były za nieodpowiednie zachowanie, przeszkadzanie innym i nieposłuszeństwo (tabela 2). Dziewczynki dodatkowo za gadulstwo, głośną zabawę i kłótnię, a chłopcy - agresję i zaczepki. Nauczycielki większą uwagę zwracały na gadulstwo i głośną zabawę dziewczynek, mimo tego że - jak wynika z moich obserwacji - chłopcy w rozmowności w niewielkim stopniu ustępowali koleżankom, a już z pewnością bawili się i zachowywali od nich głośniej (oprócz chłopców $\mathrm{z}$ przedszkola $\mathrm{D})$. 


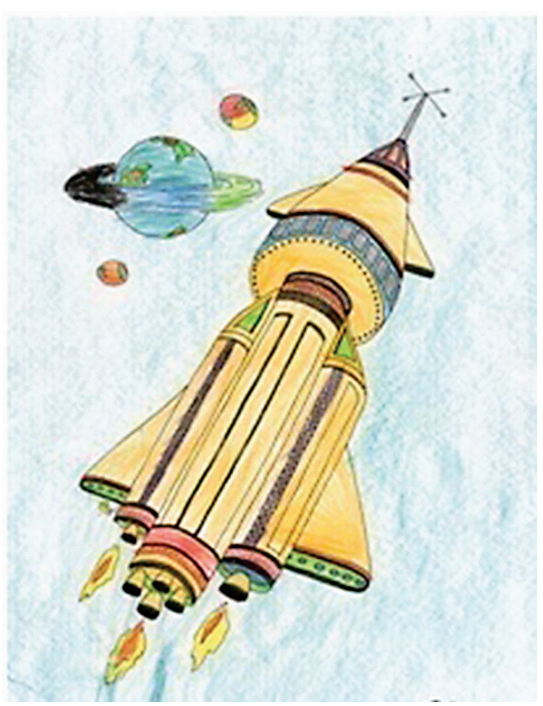

Fotografia 1. Kinga. Przedszkole A

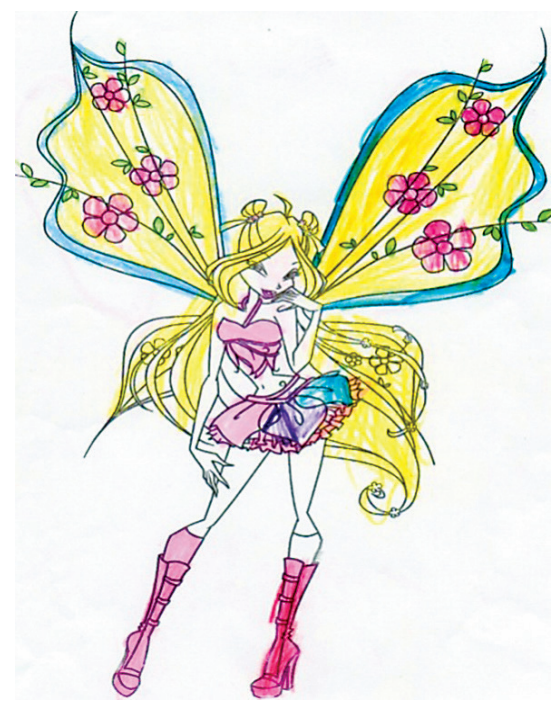

Fotografia 2. Janek. Przedszkole C

W ogólnym zestawieniu odpowiedzi nauczycielek więcej przewinień przypisały dziewczynkom niż chłopcom, choć wcześniej podkreślały, że dziewczynki są ogólnie grzeczniejsze. O czym może to świadczyć?

Zanim odpowiem na to pytanie, chcę podkreślić fakt, iż we wszystkich przedszkolach w zasadzie było tyle samo dziewcząt (55) i chłopców (56). Wyższy wskaźnik zachowań negatywnych dziewcząt niż chłopców, na które zwróciły uwage nauczycielki, można tłumaczyć następująco:

a) zachowanie dziewczynek jest bardziej kontrolowane niż zachowanie chłopców, stąd też więcej wychwyconych „uchybień”;

b) dziewczynki mają mniejsze przyzwolenie społeczne na złe zachowania i nawet te małe przewinienia są im wytknięte;

c) dziewczynki faktycznie przejawiały więcej zachowań nagannych niż chłopcy - były bardziej niegrzeczne.

Nauczycielki jak mantrę powtarzały: „Dzieci teraz są inne niż kiedyś, a szczególnie zmieniły się dziewczynki. To już nie te grzeczne, spokojne istotki, są coraz bardziej hałaśliwe, zaborcze, agresywne i mniej posłuszne”, choć jednocześnie uważały je za grzeczniejsze niż chłopcy. Wydaje się, że przywiązanie do tradycyjnego stereotypu grzecznej i posłusznej dziewczynki uwrażliwiało nauczycielki na wychwytywanie i surowsze reagowanie na odstępstwa wychowanek od tych standardów. Oznaczałoby to zatem, że nauczycielki hamowały próby usamodzielniania się i emancypacji dziewczynek, które - być może - w domu miały większe przyzwolenie na swobodne zachowanie. 
Badania pokazały również, że wszystkie nauczycielki stosowały podobne kary - zwykle była to izolacja albo przesadzanie dziecka w inne miejsce (tabela 3).

Tabela 2. Przyczyna zastosowania kary wobec dziewczynek i chłopców

\begin{tabular}{|c|c|c|c|}
\hline $\begin{array}{c}\text { Za co karane byly } \\
\text { dziewczynki? }\end{array}$ & $\begin{array}{c}\text { Ilość } \\
\text { odpowiedzi }\end{array}$ & $\begin{array}{c}\text { Za co karani byli } \\
\text { chłopcy? }\end{array}$ & $\begin{array}{c}\text { Ilość } \\
\text { odpowiedzi }\end{array}$ \\
\hline $\begin{array}{l}\text { „Za gadulstwo na zajęciach, } \\
\text { niesłuchanie, przeszkadzanie” } \\
\text { (A1); } \\
\text { „Gadulstwo, przeszkadzanie na } \\
\text { zajęciach lub w zabawie” (B1); } \\
\text { „Przeszkadzanie na zajęciach, } \\
\text { niegrzeczne zachowanie } \\
\text { w stosunku do innych. Szybciej } \\
\text { »kruszeją«, dziewczynki same } \\
\text { pytają czy już mogą wrócić } \\
\text { do zabawy. Są dziewczynki, } \\
\text { które unoszą się honorem i nie } \\
\text { proszą, są też - i to częściej - } \\
\text { chłopcy. Chłopcy są bardziej } \\
\text { dumni” (B2); } \\
\text { „Za nieodpowiednie zachowa- } \\
\text { nie” (C1); } \\
\text { „Amelka przeszkadzała innym, } \\
\text { zabierała dzieciom klej, papier. } \\
\text { Kłóciła się z Dominikiem” (C2); } \\
\text { „Gadulstwo, kłótnie, nieposłu- } \\
\text { szeństwo” (D1); } \\
\text { „Hałaśliwą zabawę, niepo- } \\
\text { słuszeństwo, bieganie po sali, } \\
\text { przeszkadzanie innym” (D2) }\end{array}$ & $\begin{array}{l}\text { Przeszkadzanie } \\
\text { innym - } 4 \\
\text { Gadulstwo - } 3 \\
\text { Nieposłuszeństwo -3 } \\
\text { Złe zachowanie - } 3 \\
\text { Kłótnia - } 2 \\
\text { Głośna zabawa - } 1\end{array}$ & $\begin{array}{l}\text { „Za agresję” (A1); } \\
\text { „Za złe zachowanie, } \\
\text { przeszkadza innym” } \\
\text { (A2); } \\
\text { „Za zachowanie, } \\
\text { przejawy agresji” (B1); } \\
\text { „Tak samo, jak } \\
\text { dziewczynki” [tzn. } \\
\text { przeszkadzanie, } \\
\text { niegrzeczne zachowa- } \\
\text { nie, nieodpowiednie } \\
\text { zachowanie - uzup. } \\
\text { B.P.] (B2, C1); } \\
\text { „Za przeszkadzanie } \\
\text { innym, zaczepki, } \\
\text { nieodpowiednie słow- } \\
\text { nictwo, nieposłuszeń- } \\
\text { stwo” (D1) }\end{array}$ & $\begin{array}{l}\text { Złe zachowanie -4 } \\
\text { Przeszkadzanie } \\
\text { innym - } 3 \\
\text { Agresja, zaczepki - } 3 \\
\text { Nieposłuszeństwo - } 1 \\
\text { Nieodpowiednie } \\
\text { słownictwo - } 1\end{array}$ \\
\hline
\end{tabular}

Źródło: opracowanie własne na podstawie przeprowadzonych wywiadów. W kolumnie drugiej i czwartej liczba oznacza, ile nauczycielek wskazało na dany rodzaj zachowań

Tabela 3. Rodzaje kar wymierzanych dzieciom w przedszkolu

\begin{tabular}{|c|c|c|c|}
\hline $\begin{array}{c}\text { Kara stosowana wobec } \\
\text { dziewcząt }\end{array}$ & Ogólna ilość & $\begin{array}{l}\text { Kara stosowana } \\
\text { wobec chłopców }\end{array}$ & Ogólna ilość \\
\hline $\begin{array}{l}\text { „Przesadzanie w inne miejsce, } \\
\text { izolacja od grupy” (A1); } \\
\text { „Upomnienie, przesadza do } \\
\text { innego stolika, siedzi osobno” } \\
\text { (A2); } \\
\text { „Odosobnienie, np. sadzam na } \\
\text { krześle przy ścianie, z dala }\end{array}$ & $\begin{array}{l}\text { Izolacja od dzieci - } 5 \\
\text { Przesadzenie - } 3 \\
\text { Upomnienie - } 1 \\
\text { Zakaz zabawy - } 1\end{array}$ & $\begin{array}{l}\text { „Sadzam do stolika } \\
\text { i daję układankę, puz- } \\
\text { zle, klocki (dla wyci- } \\
\text { szenia), jeśli powtarza } \\
\text { się złe zachowanie to } \\
\text { odprowadzam dziecko } \\
\text { do maluszków” (A1); }\end{array}$ & $\begin{array}{l}\text { Przesadzenie - } 5 \\
\text { Izolacja od dzieci - } 4 \\
\text { Odsyłanie do młod- } \\
\text { szej grupy - } 1\end{array}$ \\
\hline
\end{tabular}




\begin{tabular}{|c|c|c|c|}
\hline $\begin{array}{c}\text { Kara stosowana wobec } \\
\text { dziewcząt }\end{array}$ & Ogólna ilość & $\begin{array}{l}\text { Kara stosowana } \\
\text { wobec chłopców }\end{array}$ & Ogólna ilość \\
\hline $\begin{array}{l}\text { od dzieci na } 5-10 \text { min. zwykle } \\
\text { dziecko przychodzi same } \\
\text { i przeprasza” (B1); } \\
\text { „Odłączam dziecko od grupy, } \\
\text { by przemyślało swoje zachowa- } \\
\text { nie” (B2); } \\
\text { „Izolowanie od zabawy i dzie- } \\
\text { ci” (C1); } \\
\text { „Przesadzeniem” (C2); } \\
\text { „Nie bawią się" (D1) }\end{array}$ & & $\begin{array}{l}\text { „Sadzam go samego } \\
\text { przy innym stoliku, } \\
\text { wtedy wykona polece- } \\
\text { nie lepiej i dokładniej } \\
\text { niżby siedział z inny- } \\
\text { mi dziećmi” (B1); } \\
\text { „Tak samo jak dziew- } \\
\text { czynki” (B2, C1); } \\
\text { „Zostaje przesadzony } \\
\text { do stolika, gdzie jest } \\
\text { sam” (C2); } \\
\text { „To izolacja” (D1); } \\
\text { „Odosobnienie, sadza- } \\
\text { nie przy stole” (D2) }\end{array}$ & \\
\hline
\end{tabular}

Źródło: opracowanie własne

Pierwsza z kar polegała na całkowitym odizolowaniu dziecka od koleżanek, kolegów lub całej grupy, z wyprowadzeniem go do innej sali włącznie. Drugi rodzaj kary, przesadzenie, dotyczył zmiany miejsca - jeśli dzieci siedziały na dywanie, to „niegrzeczne” dziecko musiało za karę usiąść obok innego dziecka, najczęściej płci przeciwnej. Podobnie podczas pracy przy stolikach - dziecko przesadzane było do drugiego stolika. W rozumieniu nauczycielek przebywanie dziecka z przedstawicielem/-ką płci przeciwnej spełnia podwójną funkcję: uspakaja i karze jednocześnie. Taki sposób karania dzieci prowadzi do antagonizmów płciowych, separacji oraz nieumiejętności współdziałania, utrwalając stereotypową polaryzację rodzajową.

Wymierzane dzieciom kary były przyjmowane w różny sposób, ale zwykle budziły niezadowolenie. Oto dwa przykłady reakcji dzieci na karę:

1) Zajęcia plastyczne w przedszkolu C. Dzieci siedziały przy stolikach, ich zadaniem było wykleić bibułą sylwetkę wiewiórki. Damian rozmawiał, przeszkadzał koleżankom i kolegom siedzącym obok niego. Dzieci skarżyły się na niego, mówiąc, że im przeszkadza i zabiera klej. Pani C2 po trzech ustnych upomnieniach, które nie przyniosły zamierzonego skutku, nakazała chłopcu siąść przy innym, pustym stoliku. Niezadowolony, mrucząc coś pod nosem, wziął swój karton i poszedł do wyznaczonego stołu. Nauczycielka zaniosła mu bibułę i klej. Po chwili pracy w osamotnieniu podszedł do nauczycielki i zapytał, czy może wrócić na swoje miejsce. Pani się nie zgodziła. Sytuacja powtórzyła się jeszcze trzykrotnie, ale nauczycielka konsekwentnie na jego prośbę odpowiadała „nie”. Rozłoszczony chłopiec mamrotał coś pod nosem, sapał, wreszcie zaczął kopać stolik. Zmęczony tą 
czynnością usiadł i po kilku minutach zabrał się do pracy. Przy końcu zajęć okazało się, że Damian dokończył wyklejankę i zrobił to bardzo dobrze;

2) Swobodna zabawa dzieci w przedszkolu B. Do grupy dziewczynek bawiących się w kąciku domowym podeszła Karolina i bez pytania o zgodę przyłączyła się do ich zabawy. Początkowo było spokojnie, ale po kilku minutach Karolina wprowadziła „swoje rządy”, na które nie zgodziły się pozostałe koleżanki. Zaczęła się kłótnia i wyszarpywanie sobie zabawek. Nauczycielka, zobaczywszy zachowanie dziewczynek, postanowiła zareagować. Poprosiła Karolinę (dziewczynkę, która dołączyła do zabawy) o zgodną zabawę. Jednak nie nastąpiła poprawa, więc pani B2 zawołała dziewczynkę do biurka i kazała jej usiąść obok na krześle. Karolina siadła przy biurku i smutnym wzrokiem patrzyła na zabawę koleżanek, po około 5 minutach nauczycielka zapytała:

N.: „Karolina przemyślałaś już sprawę, czy chcesz mi coś powiedzieć?”

Karolina: „Tak”.

N.: „Będziesz się teraz grzecznie bawiła?”

Karolina: „Tak”.

N.: „Co powiesz?”

Karolina: „Przepraszam”.

Dziewczynka odeszła od biurka, wzięła z półki jakąś układankę i siadła przy stoliku (OB2/5).

W tej sytuacji interesujące jest, że pani B2 powiedziała mi, że dziewczynki szybciej „miękną”, a chłopcy są bardziej „honorowi”.

Postępowanie nauczycielek jest wymownym zaprzeczeniem głoszonych przez nie deklaracji o „takim samym traktowaniu dzieci”. Pani C2 posadziła chłopca przy stoliku daleko od siebie, dała mu materiały i zadanie do wykonania. Sytuacja, w jakiej się znalazł, pozwalała mu na dokonanie wyboru: zrobić, co pani kazała lub nie, uczyła więc niezależności i samodzielnego podejmowania decyzji. Zachowanie nauczycielki zachęcało również chłopca do stawiania oporu: skoro pani trzy razy odmówiła mu powrotu na swoje miejsce, to znaczy, że nie warto prosić. Poza tym nie zmuszała do przeprosin. W rezultacie - choć po pewnym czasie - chłopiec wykonał wyznaczone zadanie.

W przypadku dziewczynki było inaczej. Nauczycielka posadziła ją przy biurku, blisko siebie, nie dając żadnego zadania do wykonania. Tego rodzaju presja nie daje dziecku wyboru i prowadzi do uczenia się zależności i podporządkowania. Wychowawczyni, nie doczekawszy się żadnej reakcji ze strony dziewczynki (prośby, przeprosin), sama wyszła z inicjatywą rozwiązania konfliktu - wymusiła na dziewczynce deklaracje grzecznego zachowania oraz przeprosiny. Zaobserwowana sytuacja jest zaprzeczeniem opinii nauczycielki, że dziewczynki szybciej miękną, bo nie 
dość, że wychowanka nie prosiła o odwołanie kary, to nie wróciła też do przerwanej zabawy - zajęła się zupełnie czymś innym. To jej, a nie chłopca, postępowanie można określić jako „honorowe”. Postępowanie obu nauczycielek nie wynikało z rzeczywistych zachowań dzieci, lecz podyktowane było stereotypowymi uprzedzeniami i miały skłonić dzieci do zachowania zgodnie z rodzajowymi standardami.

W przekazywaniu komunikatów nagradzających/karzących dzieci (dziewczynek i chłopców) istniały subtelne różnice, np. nauczycielki bardziej akcentowały nagrodę skierowaną do chłopców. Podczas nagradzania chłopca częściej zwracały się do całej grupy, używając m.in. takich zwrotów: "Zobaczcie, jak to zrobił Szymon”, „Posłuchajcie, co powiedział Konrad”, „Widzicie, jak Maciek się postarał?” itp. Nagradzanie dziewczynek miało natomiast bardziej powszednią oprawę - wychowawczyni zwracała się bezpośrednio do konkretnej dziewczynki: „Bardzo dobrze, Aga”, „Świetnie, Asiu”, „Lauro, jestem z ciebie zadowolona” itp. Prawdopodobnie taki sposób nagradzania miał zachęcić chłopców do lepszego zachowania i do większej aktywności na zajęciach. Generalnie z moich obserwacji wynika, że dziewczynki częściej zasługiwały na pochwałę i być może dla nauczycielek było to normalne zjawisko, niewymagające aż takiego wyróżnienia. $Z$ kolei pochwalenie chłopca na forum grupy miało zmotywować go do pracy w przyszłości. Takie postępowanie to dla dzieci wyraźny komunikat: to, co robią chłopcy/mężczyźni zasługuje na większe uznanie niż taka sama praca dziewczynek/kobiet; dla chłopców/mężczyzn zarezerwowana jest sfera publiczna, dla dziewczynek/kobiet - prywatna; normą jest, że chłopcy/mężczyźni są bardziej „obecni” i eksponowani społecznie, a dziewczynki/kobiety marginalizowane. Zatem mimo deklarowanych w ankiecie przekonań „równościowych”, niestereotypowych nauczycielki swoim zachowaniem umacniały androcentryczne widzenie świata i przekazywały dzieciom stereotypy płciowe.

Pewne różnice można było też zauważyć w sposobie karania dzieci. Z moich obserwacji wynika, że chłopcy otrzymywali więcej niż dziewczynki krytycznych uwag dotyczących zachowania, ale nie zawsze towarzyszyła im kara. Wyrazem tego były m.in. kierowane do nich uwagi, ostrzeżenia, upomnienia i powtarzanie komunikatów itp. Poza tym niewłaściwe zachowanie chłopców nie wywoływało w nauczycielkach tak dużego zniecierpliwienia, jak zachowanie dziewcząt. Nauczycielki wymagały i oczekiwały od nich większego podporządkowania, posłuszeństwa, a problem pojawiał się wówczas, gdy któraś z nich nie stosowała się do uwag wychowawczyni. Nie były to sytuacje nazbyt częste, ale (albo może dlatego) nauczycielki bardziej je pamiętały, zwracały na nie większą uwagę. Do z natury mniej posłusznych i mniej zdyscyplinowanych chłopców były już przyzwyczajone, lecz niegrzeczna, krnąbrna i nieposłuszna dziewczynka stanowiła dla nich nowe i nietypowe wydarzenie, z którym się jeszcze nie oswoiły. Świadczyły o tym zarówno obserwowane przeze mnie zachowania, jak i wypowiedzi nauczycielek. 


\section{PODSUMOWANIE}

Zaprezentowane badania pozwalają zwrócić uwagę na kilka faktów. Przeprowadzone obserwacje nie pokrywały się z wypowiedziami nauczycielek: nauczycielki (bez wyjątku) twierdziły, że traktują dzieci jednakowo i nie ma dla nich różnicy, czy to chłopiec, czy dziewczynka, a tymczasem zarejestrowałam, że jest inaczej. Jest to potwierdzenie nieuświadomionego oddziaływania nauczycielek na dzieci w sferze wytwarzania stereotypów płciowych i odmiennego traktowania wychowanków ze względu na płeć. Wychowawczynie kierowały do chłopców więcej komunikatów dyscyplinujących i kontrolujących niż do dziewczynek i wyrażały je surowszym tonem. Ale jednocześnie wykazywały większą tolerancję na ich hałaśliwe zachowanie, łamanie zasad i umów. Uważały dziewczynki za grzeczniejsze i bardziej posłuszne, częściej też wyrażały aprobatę dla ich zachowania. Pomimo tego stawiały im wyższe wymagania i oczekiwały większego podporządkowania oraz subordynacji. Nasuwa się zatem wniosek, iż istota zabiegów socjalizacyjnych stosowanych przez nauczycielki polegała na stosowaniu wobec dziewczynek wzmożonej kontroli, uczeniu uległości i posłuszeństwa (jednym z przejawów takiego podejścia było chociażby powierzanie im pewnych obowiązków domowych - czynności porządkowych), chłopcom natomiast pozostawianiu większego marginesu swobody. Interakcje nauczycielki z dziewczynkami wzmacniały zatem konformizm i zależność, a z chłopcami - samodzielność, niezależność i odwagę (zob. Best, Williams 2002, s. 139). Podczas zajęć nauczycielki częściej kontrolowały pracę chłopców, zachęcały ich do większej staranności, sumienności i doprowadzenia jej do końca (dziewczynki zwykle to robiły bez dodatkowych zachęt). Jak dowodzą badania (Meighan 1993, s. 332-333; Chomczyńska-Miliszkiewicz 2002, s. 143-144; Pankowska 2005, s. 68-71; Kopciewicz 2004, s. 76-77; Bochno 2009, s. 181-191), chłopcy, którzy doświadczają zainteresowania nauczycielki, stymulowani są do rozwoju ciekawości poznawczej, zaufania we własne siły i eksplorowania świata. Są to cechy, które zaczynają owocować w późniejszych latach edukacji, kiedy zmniejsza się nacisk na kontrolę, a zwiększa na samodzielność.

\section{LITERATURA}

Angrosino M., 2010, Badania etnograficzne i obserwacyjne. Warszawa, PWN.

Barnes D., 1988, Nauczyciel i uczniowie. Od porozumiewania się do kształcenia.

Warszawa, WSiP.

Best D.L., Wiliams J.E., 2002, Perspektywa międzykulturowa. W: B. Wojciszke (red.), Kobiety i mężczyźni: odmienne spojrzenie na różnice. Gdańsk, GWP, 118-145. 
Blumer H., 1984, Społeczeństwo jako symboliczna interakcja. W: E. Mokrzycki (red.), Kryzys i schizma. Warszawa, PIW.

Bochno E., 2009, Stereotyp płci czy płeć języka? Szkolne interakcje komunikacyjne nauczycielek z uczennicami i uczniami. W: L. Kopciewicz, E. Zierkiewicz (red.), Koniec mitu niewinności? Płeć i seksualność w socjalizacji i edukacji. Warszawa, Wydawnictwo Eneteia, 181-191.

Chomczyńska-Miliszkiewicz M., 2002, Edukacja seksualna w społeczeństwie współczesnym. Konteksty pedagogiczne i psychologiczne. Lublin, Wydawnictwo UMCS.

Konarzewski K., 1995, Problemy i schematy. Pierwszy rok nauki szkolnej dziecka. Warszawa, Wydawnictwo Akademickie Żak.

Kopciewicz L., 2004, Schematy rodzaju (gender) w pracy pedagogicznej nauczycielek edukacji wczesnoszkolnej. W: M. Chomczyńska-Rubacha (red.), Płeć i rodzaj w edukacji. Łódź, WSHE, 75-84.

Kwiatkowska H., 2000, Kształcenie nauczycieli a nowe sposoby uczenia się człowieka.

W: Kwiatkowska H., Lewowicki T., Dylak S. (red.), Współczesność a kształcenie nauczycieli. Warszawa, WSP, ZNP.

Meighan R., 1993, Socjologia edukacji. Toruń, Wydawnictwo UMK.

Nęcki Z., 1996, Komunikacja międzyludzka. Kraków, Wydawnictwo Profesjonalnej Szkoły Biznesu.

Okoń W., 2007, Nowy słownik pedagogiczny. Warszawa, Wydawnictwo Akademickie Żak. Pankowska, D., 2005, Wychowanie a role płciowe. Gdańsk, GWP.

Rubacha K., 2001, Badania etnograficzne w edukacji. „Teraźniejszość - Człowiek Edukacja”, nr 1.

Schaffer R.H., 2013, Psychologia dziecka. Warszawa, PWN.

Schieffelin B.B., Ochs E., 1995, Socjalizacja języka. W: A. Brzezińska, T. Czub, G. Lutomski, B. Smykowski (red.), Dziecko w zabawie i świecie języka. Poznań, Wydawnictwo Zysk i S- ka.

Tillmann K. J., 2010, Teorie socjalizacji. Społeczność, instytucja, upodmiotowienie. Warszawa, PWN.

\section{INTERACTIONS BETWEEN PRESCHOOLERS AND THEIR TEACHERS IN THE PROCESS OF GENDER SOCIALIZATION}

\footnotetext{
Abstract: In the socialization process, a child learns social interactions, interpersonal relations and coexistence in the group, social standards and standards of conduct. Additionally, children develop their personality and character. One of the most essential part of the socialization
} 
process is the preparation to fulfill male and female roles. Preschool significantly affects the formation of gender roles. This research involves interactions between preschoolers and their teachers. Furthermore, it deals with the influence of the interactions on the development of child's social-cultural gender.

Keywords: socialization, interactions, sex, gender 